(C) 2012. This manuscript version is made available under the CC-BY-NC-ND 4.0 license

http://creativecommons.org/licenses/by-nc-nd/4.0/

\title{
Will small energy consumers be faster in transition? Evidence from the early shift from coal to oil in Latin America*
}

\begin{abstract}
M.d.Mar Rubio
Department of Economics, Universidad Publica de Navarra, 31006 Pamplona, Spain. e-mail: mar.rubio@unavarra.es. Tel: (34) 948169 706. Fax: (34) 948169721
\end{abstract}

and

Mauricio Folchi

Department of Historical Sciences, Universidad de Chile; mfolchi@u.uchile.cl

\footnotetext{
* This work is the result of research projects (SEJ2007-60445 and ECO2010-15882) co-financed by the Spanish Ministry of Science and Technology and the European Union through FEDER. The authors would like to thank the colleagues and research assistants to whom we are indebted for their work and suggestions. Thanks to Albert Carreras, César Yáñez, Xavier Tafunell, Frank Notten, Anna Carreras-Marín, Marc Badia-Miró, José Jofré, José Peres-Cajías and Carolina Román. Two anonymous referees were very helpful in improving the final version. All remaining errors are solely ours.
} 


\title{
Will small energy consumers be faster in transition? Evidence from the early shift from coal to oil in Latin America
}

\begin{abstract}
This paper provide evidence of the early transition from coal to oil for 20 Latin American countries over the first half of the $20^{\text {th }}$ century, which does not fit the transition experiences of large energy consumers. These small energy consumers had earlier and faster transitions than leading nations. We also provide evidence for alternative sequences (inverse, revertible) in the transition from coal to oil. Furthermore, we demonstrate that 'leapfrogging' allowed a set of follower economies to reach the next rung of the energy ladder (oil domination) 30 years in advance of the most developed economies. We examine these follower economies, where transition took place earlier and faster than the cases historically known, in order to understand variation within the energy transitions and to expand the array of feasible pathways of future energy transitions. We find that being a small energy consumer makes a difference for the way the energy transition takes place; but also path dependence (including trade and technological partnerships), domestic energy endowment (which dictates relative prices) and policy decisions seem to be the variables that shaped past energy transitions.
\end{abstract}

Keywords: energy transition; coal and petroleum consumption; Latin America 


\section{INTRODUCTION}

Studies dealing with the energy history of any country point to a typical phenomenon, present in all cases. Over time, stages can be identified in which an energy carrier clearly predominates, and then gradually begins to recede with the advance of a new energy source, which eventually replaces it. This phenomenon has become known as energy transition and is defined as the gradual substitution of one energy source or energy carrier by another, through history. Historically, the logic of this phenomenon has been the replacement towards energy carriers of higher quality. The usefulness of an energy system is determined by a complex combination of physical, technical, economic, and social attributes. These include gravimetric and volumetric energy density, power density, emissions, cost and efficiency of conversion, financial risk, amenability to storage, risk to human health, and ease of transport. ${ }^{1}$ There it follows that the energy transition could be understood as a process of energy modernisation. $^{2}$

The energy transition phenomenon can only be empirically described as an historical phenomenon. And the only historical path described so far is that of the Western world. Nearly all the evidence accumulated regarding past energy transitions refers to advanced economies (Austria, Canada, Italy, Japan, Netherlands, Spain, Sweden, the United Kingdom and, the United States). ${ }^{3}$ The primary reason for this is that energy-transition evidence requires long-term data (over a century) of energy consumption. From such evidence, it derives a set of common features regarding pace, irreversibility and sequence within energy transitions. The aforementioned countries were historically slow in

$1 \quad$ Cleveland and Kaufmann (2008).

2 Grüble proposes a more complex definition of energy transitions "in terms of three interdependent characteristics: quantities (growth in amounts of energy harnessed and used), structure (which types of energy forms are harnessed, processed, and delivered to the final consumers as well as where these activities take place), and quality (the energetic and environmental characteristics of the various energy forms used). See Grüble (2004: 163).

3 Austria: (Krausmann and Haberl 2002), Canada: (Steward, 1978); Italy: (Malanima 2006), Japan: (Hunt and Ninomiya 2005), Netherlands: (Gales et al. 2007), Spain: (Rubio 2005), Sweden: (Kander 2002), the United Kingdom (UK): (Fouquet and Pearson 1998; Fouquet, 2010; Warde 2007) and the United States (USA): (Schurr and Netschert 1977) 
permanently altering their energy baskets. In several of the crucial stages, such as the passage from organic to mineral energy or the switch from coal to oil, the duration of the process ranged from several decades to over a century. The available evidence also indicates that transitions in the past followed an irreversible progression. Inferior energy carriers were abandoned for superior ones, as the countries climbed the energy ladder step by step, ever upwards. In the Western world, there was also an apparent sequence among the countries that first reached the higher rungs on the ladder: leading economies typically achieved upper levels of the energy ladder first. As a consequence, future transitions are expected to be slow, with today's most advanced economies setting the pace while the rest of the world climbs the energy ladder, step by step, behind the leaders (Fouquet, 2010; Smil, 2006; Murphy, 2001; Gibbons and Blair, 1991; Lönnroth et al., 1980).

Yet, a small body of evidence on energy transitions outside of Western economies challenges the universality of the Western experience (Marcotullio and Schulz, 2007). During the past thirty years, developing countries appear to have made energy transitions earlier, faster and with greater diversity than had been understood, although they still lagged behind the leading economies. The pace may have quickened, but the sequence seems to have remained intact. Also several studies on the history of technology, science or human development show that the advance or progress in the adoption of technology is not and has not been lineal, and that in many aspects latecomers transit at faster pace than pioneers (Munford, 1934; Diamond, 1997). Will the so-called following nations take the lead and make future energy transitions ahead of the leading economies? This paper further questions the universality of the Western energy-transition experience, and the energy ladder associated to it, by providing evidence of the early transition from coal to oil for 20 Latin American countries during the first half of the $20^{\text {th }}$ century. This analysis was not possible until recently because the data were not available for these countries prior to $1950 .^{4}$ For our discussion, we make use of a new reconstruction of data on energy consumption for Latin America and the Caribbean that goes back into the $19^{\text {th }}$ century. ${ }^{5}$

4 Several studies provided punctual benchmark estimates in the first half of the 20th century, although the data were rarely comparable across the few countries studied. Benchmark estimates for years 1928, 1929 and 1939 are found respectively in the U.S. Department of 
This new evidence shows that the acceleration in the pace of transition of the follower countries is not a unique event restricted to the global economy of the $21^{\text {st }}$ century. Such acceleration has previously occurred, and followers may have earlier and faster transitions than leading nations. The new evidence points to the existence of alternative sequences (i.e., inverse, revertible) in the transition from coal to oil. Furthermore, it also demonstrates that 'leapfrogging' allowed a set of follower economies to reach the next step of the energy ladder (oil domination) thirty years in advance of the leading economies.

The evidence that the energy transition of the less-advanced countries did not fit the historical evidence of advanced nations has strong policy implications in terms of a future global energy transition for both sets of countries. For the advanced economies, the message remains intact: their transition will be slow if no action is taken. That is why it is important to identify where there is room for policy action to accelerate the process. In fact, much of the current discussion about the low carbon transition in Western economies is about the challenge of how to make it faster than previous transitions. For less-advanced countries, the set of policy actions will differ. They can, and will, make quick transitions given the right conditions, some of which are identified in this paper.

The paper is organised as follows. After this introduction, section 2 explains the reasons for focussing on the fossil-fuel transition. Section 3 provides a succinct summary of the historical evidence of fossil-fuel transitions known to date. Section 4 provides basic background information on energy consumption in Latin America prior 1950. Section 5 supplies data regarding the 20 Latin American countries showing early, accelerated and contradictory energy transition paths during the early $20^{\text {th }}$ century. In section 6 , we outline plausible explanations of the factors that foster and hinder the

\footnotetext{
Commerce (Bradley, 1931); Read (1933) and Read (1945). Only three studies provide historical series annual data on energy consumption in Latin America, namely UN-ECLA (1951), ECLA (1957), and Darmstadter et al. (1971). These studies provide data for 5, 7 and 11 countries of Latin America and the Caribbean, respectively, the earliest starting in 1925.

5 On the fundaments and orientation of the same, see Carreras et al. (2006). For an in-depth discussion of the methodological problems encountered with the reconstruction of historical statistics of energy consumption and the solutions adopted by the authors, see Folchi and Rubio (2007, 2008), and Rubio and Folchi (2005). For the general results of the data reconstruction for the period 1890-1925 see Rubio et al. (2010). Here, the data of Rubio et al. (2010) had been extended back to 1856 and forward to 1960.
} 
transition, all of which offer lessons for the future energy transitions in follower countries. In sum, this is a paper about past energy transitions that is aimed at preparing for future ones.

\section{WHY CONCENTRATE ON THE FOSSIL FUELS TRANSITION?}

There is not one single energy transition but rather various energy transitions, which can be consecutive, overlap in time or occur in parallel. One such transition is that from traditional energy sources to modern energies, that is, the abandonment of fuels such as firewood and draft animals. Another transition is that occurring within fossil fuels, from coal to petroleum and natural gas. Another transition, which relates to energy forms, is the advance of electrical energy, regardless of its source.

Evidently, an exhaustive study of energy history should include the consumption of all types of fuel, including organic fuel (firewood, peat and charcoal) and other energy sources. Nevertheless, if we are interested in identifying changes in the pattern of energy consumption in modern times, then fossil fuel consumption between 1890 and the 1950s is a fundamental indicator.

Apart from several exceptions during the $19^{\text {th }}$ and $20^{\text {th }}$ centuries (some railways, some lighting systems and some metallurgical and industrial activities), traditional fuels of organic origin have not been used in modern activities. ${ }^{6}$ Rather, they are typically used in traditional, domestic and rural activities. This explains how the per-capita consumption of organic fuels tends to remain steady over time. If a country experiences a significant increase in total energy consumption per capita, it is probable that this will be reflected in the fossil fuel category (see figure no. 1). ${ }^{7}$

\footnotetext{
The exceptions provided interesting studies: the railways and, especially, the steelworks in Minas Gerais, Brazil (where charcoal-based iron and steel production accounted for $28.7 \%$ of the total production for 1999; see Baer (1969) and Dean (1995). A critical review of the latter book can be found in Brannstrom (2005). Wood was also used in railways in Colombia and Ecuador (Restrepo, 1953). Additionally, see Caetano Bacha [2003: 211]) with regard to copper and nitrate mining in Chile; the Cuban sugar industry, etc. For the Chilean case, see Folchi (2001); for Cuba, see Funes (2004: 293-303).

7 Melosi warns that identifying wood as a pre-industrial or even primitive fuel would be erroneous in the case of North America. Effectively, in the mid-19 ${ }^{\text {th }}$ century, half of the iron was produced in the United States using charcoal (Melosi, 1982: 60). However, the importance of these cases is above all qualitative. In the case of the U.S., 95,5\% of the total firewood and charcoal consumed in 1879 was for domestic use. The remaining 4,5\% was divided up among the railways $(1,3 \%)$, the manufacturing industry (1,3\%), iron foundries $(1,0 \%)$, steam ships $(0,5 \%)$ and mining $(0,4 \%)$ (Williams, 1982: 21$)$.
} 


\section{Figure 1. Relation between total energy consumption per capita and fossil energy consumption per capita in Latin America in 1939.}

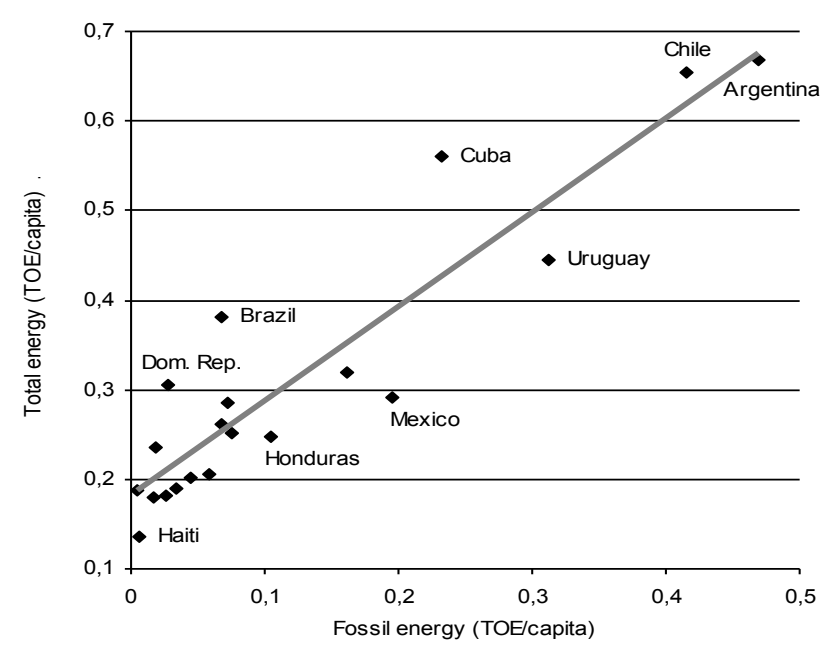

Source: Elaboration by the authors using ECLAC data (1956)

One indisputable fact among energy history studies is the positive relationship between income level and energy consumption per capita. Irrespective of space and time, high-income economies consume the most energy per capita, and low-income societies consume the least. ${ }^{8}$ In the same way, it can be said that there is a negative relationship between the proportion of organic fuel consumed per person in an economy and the level of economic production. Activities that use traditional fuels tend to generate the least economic growth as a result. Furthermore, an organic-based economy faces numerous limits to its expansion. As argued by Wrigley (2004:31), it would be impossible, for example, within the constraints of an organic economy to produce iron and steel on a

8 Economists have recognised this phenomenon since the beginning of the $20^{\text {th }}$ century; see Hobson (1914) and Carver (1924). In the same vein, Arnulf Grüble recently argued that "North-South disparities in the growth of energy-use roughly mirror disparities in income growth because growth in energy use is linked to growth in incomes," and that "the overall positive correlation between economic growth and energy growth remains one of the most important 'stylized facts' we can draw from history, even if the extent of this correlation and its patterns over time are highly variable”. (Grüble, 2004). 
scale sufficient to construct a modern rail network. It should not be surprising that the countries where the relative consumption of organic energy is high are those with the lowest income levels, as shown for Latin America in figure no. 2. Leach (1992: 116) similarly argued that, in the poorest developing countries, biomass fuels account for $60-95 \%$ of total energy use, $25-60 \%$ in middle-income countries and less than 5\% in high-income industrialised countries (with minor exceptions).

\section{Figure 2. Relationship between relative consumption of organic energy and income level in Latin America in 1939.}

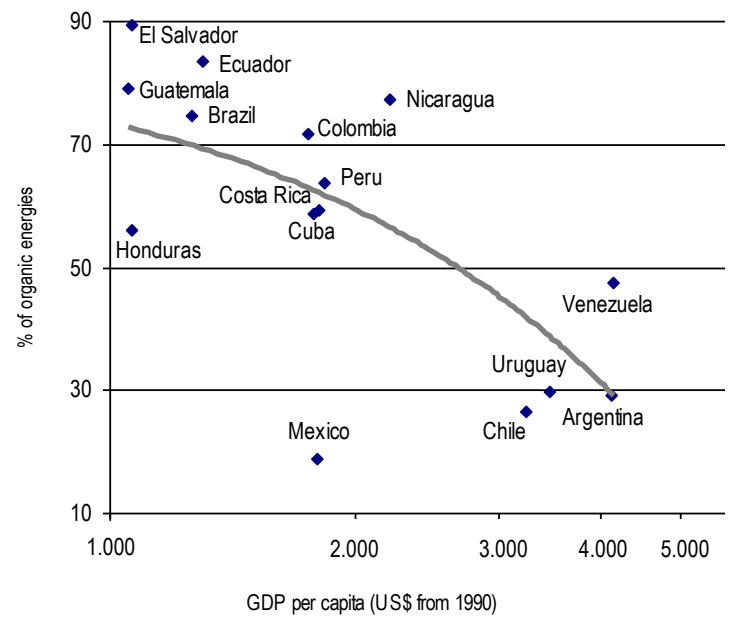

Source: Elaboration by the authors using ECLAC data (1956) and Maddison (2003) for GDP.

For these reasons, we insist that, to identify quantitative and qualitative changes in energy consumption patterns, it is necessary to focus on fossil fuels.

However, apart from the historical advance of fossil fuels, another significant area of study is the rivalry between various fossil fuels, that is, the energy transition from coal to petroleum. This change has enormous repercussions, not only for the energy sequence concerned, but also for all of the technological, economic, social, cultural and environmental changes that accompany this transition. According to Melosi, 'the concept energy transition is useful as a historical tool. In a broad sense, the concept can illuminate the evolution of material human culture, the growth and the economic development $[\ldots]$. As a mechanism of change, the energy transition influences and is influenced by 
technical, economic, political, environmental and social forces which also mark society’ (Melosi, 1982: $55){ }^{9}$

A separate issue is the generation of hydroelectric energy, which, like fossil fuels, is a modern energy form and, consequently, is counted along with fossil fuels. The proportion of hydroelectricity in the total consumption of modern energy sources varies considerably across countries but was negligible for most Latin American countries until the second part of the $20^{\text {th }}$ century. ${ }^{10}$ Nevertheless, hydroelectricity is not included in this study, which concentrates for the aforementioned reasons on fossil fuel consumption and on the energy transition within fossil fuels: the coal/petroleum ratio.

\section{THE FOSSIL- FUELS TRANSITION: TYPES AND EXPERIENCES}

The energy transition in the USA was the first historically documented (Schurr and Netschert, 1960). Between 1890 and $1955_{2}$ there were two energy transitions: from wood to coal in the $19^{\text {th }}$ century and from coal to petroleum in the early $20^{\text {th }}$ century. The use of wood (and, to a lesser extent, wind and water power) prevailed in the USA until the mid- $19^{\text {th }}$ century, with wood consumption peaking in 1885 . Coal became a leader in primary energy and fossil fuel markets from 1885 until the First World War. In 1910, coal comprised $76.8 \%$ of total primary energy and $89.2 \%$ of all fossil fuels. At that time, coal began to decline, while petroleum began to steadily increase in its market share, to the detriment of coal. ${ }^{11}$ It is noteworthy that during this advance, the use of petroleum also took various forms before replacing coal as the main energy source. The period from 1869 until the 1890 s is known as the kerosene period, when kerosene was used for lighting. Next was the fuel-oil period. At the turn of the century, gasoline fuelled internal combustion engines. Towards 1950, the market share of petroleum

9 Regarding the economic impact of the energy transition, see Rosenberg (1982), Schurr (1984), Smil (2000), Nye (1998: 71-216), and McNeill (2002). See Krausman and Haberl (2002) for a social-metabolism approach.

10 In their Latin American bundle, Darmstadter et al. (1971) found that the average hydroelectric share in 1925 was as little as $1.6 \%$, raising the total energy consumption derived from hydroelectric power to to $2.7 \%$ in 1950 . Larger shares of hydroelectricity were found in Brazil (1925: 5,7 \%, 1950: 9,2 \%) (Darmstadter et al., 1971: pp.666-669)

11 Analysis of the circumstances that prompted the advance of petroleum in the USA at the beginning of the $20^{\text {th }}$ century and of the strategies employed by petroleum companies to gain market share can be found in Pratt (1981). See also Melosi (1982: 56). 
in the energy market was already greater than that of coal and constituted over $50 \%$ of the total amount of energy consumed. In the early 1970 s, coal's share on the fossils basket had decreased to $20 \%$, while that of petroleum (plus gas) reached about $80 \%$, while fossils represented $95 \%$ of the total primary energy consumption.

A similar process occurred in European countries but with one important difference: coal endured for many more years. In the United Kingdom for example, coal's era of predominance of coal began much earlier (at the end of $18^{\text {th }}$ century) and ended much later. ${ }^{12}$ In the years following 1947 , the United Kingdom was still dependent on coal (90\% of primary energy consumed) and 'the energy policy of the country was basically still a coal policy' (Peake, 1994). Coal consumption in Great Britain reached a historical peak in 1950 and did not fall below 50\% until 1970. In the early 1950 s, coal comprised approximately $70 \%$ of the total energy consumed in many European countries, whilst in the USA it represented approximately $30 \%$ of the total energy consumed. It was only in the 1960 s and 1970s that there was a sharp decline in the percentage of coal as a proportion of total energy consumed in European countries. For example, the percentage of coal consumed in Germany fell from $90 \%$ in 1955 to $32 \%$ twenty years later. In France, the percentage of coal consumed dropped from $70 \%$ to $18 \%$ during the same period. In the Netherlands, where natural gas had been exploited since the 1960s, the percentage of coal fell from $73 \%$ in 1955 to non-existent levels in the 1970s (Dunkerley, 1980: 107). In Italy and Sweden, the Second World War marked the shift to petroleum, whereas in Spain, petroleum consumption became predominant only at the end of the $1960 \mathrm{~s} .{ }^{13}$ Table 1 summarises the years in which several industrialised countries made the transition from coal to oil, essentially during the second half of the $20^{\text {th }}$ century.

\footnotetext{
12 The estimates of Warde (2007) include all forms of energy (organic and modern), only by the 18th coal become the predominant energy carrier, while it was widely used centuries before.

13 Rubio ICE (2005); Gales et al. (2007); Bartoletto and Rubio (2008).
} 


\section{Table 1: Fossil fuel transition date for several advanced economies}

\begin{tabular}{cc} 
Country & $\begin{array}{c}\text { Year in which } \\
\text { oil became } \\
\text { permanently } \\
\text { prevalent over } \\
\text { coal }\end{array}$ \\
\hline USA & 1951 \\
Portugal & 1951 \\
Sweden & 1953 \\
Italy & 1953 \\
Japan & 1961 \\
Netherlands & 1964 \\
Spain & 1966 \\
England and Wales & 1971
\end{tabular}

Sources: (Schurr and Netschert, 1960), Portugal: (Teives Henriques, 2011), Sweden (Kander, 2002), Italy (Malanima, 2006), Japan (EMC, 1996), Netherlands (Gales, unpublished), Spain (Rubio, 2005), England and Wales (Warde, 2007)

A common assumption within the energy-transition literature is that, after the USA and the industrialised European countries, all countries in the process of economic modernisation would have shown, with a certain time lag (according to the relative economic development gap of each country), the same pattern of energy succession in three phases, the energy ladder: biomass, coal and petroleum (Bashmakov, 2007; Burke, 2011; Grübler, 2004). A similar path is expected in the transition from coal to petroleum. Nevertheless, in spite of the regularity of this phenomenon in the USA and Western Europe, the energy transition is a complex phenomenon, governed by a variety of forces and circumstances. Thus, we can expect the energy transition to occur in accordance with the USA or European cases only in those countries where the set of determining factors and circumstances are similar. In this vein, Marcotullio and Schulz (2007) compare the recent energy transitions in developing countries (c. 1970-2000) with the USA historical experience, i.e., the historical moment at which the USA had similar income levels to those developing countries. Marcotullio and Schulz demonstrate that, given similar income levels, the energy transition in developing countries occurs sooner and more 
quickly, especially in the most rapidly developing economies. Our findings concur, but with the caveat that the transitions in developing economies may also take distinct forms.

\section{ENERGY IN LATIN AMERICA PRIOR TO THE 1950s}

Before discussing the energy transitions, we should first provide background information regarding the Latin American economies and their primary energy consumption in the first half of the $20^{\text {th }}$ century. ${ }^{14}$ Most Latin American countries were net importers of coal and petroleum products, primarily from the United Kingdom, but also from the United States and Germany. Within the region, coal was found in sizeable amounts only in Chile, Mexico and Brazil, and, in all cases, the quantity was insufficient to fulfil national requirements. Eight Latin American countries were oil producers and exporters by the 1930s - Argentina, Colombia, Bolivia, Ecuador, Trinidad \& Tobago, Mexico, Peru, and Venezuelaand the last three played an active role as suppliers within the region. ${ }^{15}$

Several benchmarks noted in the annual database compiled by Rubio et al. (2010) regarding Latin America's energy consumption from 1890 to 1925 shed light on a few essential facts. Table 2 provides the levels of modern energy consumption — of coal, petroleum and hydroelectricity - per 1,000 habitants for the years 1890, 1900, 1913 and 1925 for 17 Latin American countries. The first noteworthy observation is the wide gap in primary energy consumed across the subcontinent. The four largest consumer countries consumed, on average, 18 times more energy per capita than the remaining thirteen countries in 1890; the proportion was reduced to 6 times by 1925 . Throughout the data set, the largest consumer country consumed several hundred times more energy per capita than the smallest consumer country.

The low consumption levels of the less-consuming countries are the second issue worth noting. In fact, the entire region had a very low level of energy consumption. Table 2 supplies two measures outside the region: the USA and Spain. The average energy consumption per capita in Latin America was less than $2 \%$ of the USA's. Yet, the USA was already the most energy-intensive country in the

\footnotetext{
${ }^{14}$ This section primarily derives from Rubio et al. (2010)

${ }^{15}$ Rubio (2006)
} 
world, and its energy consumption per capita was far higher than that of any other country. Relative to Spain, a relatively backward country at the time, the leading economies of the region-Argentina, Chile, Cuba, Uruguay, and even Mexico by the mid-1920s—-had higher energy consumption per capita. This is consistent with the body of knowledge regarding GDP and migratory flows over that same period. At the time, those five Latin American countries were richer than Spain and many other countries in peripheral Europe.

Table 2

Levels of primary modern energy consumption per capita in Latin America and the Caribbean for the years 1890, 1900, 1913 and 1925

\begin{tabular}{|c|c|c|c|c|c|c|c|}
\hline \multicolumn{2}{|c|}{1890} & \multicolumn{2}{|c|}{1900} & \multicolumn{2}{|c|}{1913} & \multicolumn{2}{|c|}{1925} \\
\hline Country & TOE/cap.* & Country & TOE/cap.* & Country & TOE/cap.* & Country & TOE/cap.* \\
\hline Argentina & 116.90 & Argentina & 122.90 & Argentina & 335.00 & Argentina & 331.00 \\
\hline Brazil & 33.30 & Brazil & 34.50 & Brazil & 76.70 & Brazil & 75.10 \\
\hline Chile & 171.50 & Chile & 189.50 & Chile & 503.80 & Chile & 490.30 \\
\hline Colombia & 8.70 & Colombia & 5.50 & Colombia & 3.40 & Colombia & 26.50 \\
\hline Costa Rica & 13.30 & Costa Rica & 26.40 & Costa Rica & 89.30 & Costa Rica & 113.60 \\
\hline Cuba** & 114.30 & Cuba & 158.30 & Cuba & 391.70 & Cuba & 484.00 \\
\hline Dom. Rep. & 5.80 & Dom. Rep. & 8.30 & Dom. Rep. & 16.90 & Dom. Rep. & 41.40 \\
\hline Ecuador & 0.50 & Ecuador & 0.90 & Ecuador & 10.20 & Ecuador & 21.10 \\
\hline El Salvador & 0.40 & El Salvador & 0.50 & El Salvador & 1.90 & El Salvador & 12.60 \\
\hline Guatemala & 0.40 & Guatemala & 1.50 & Guatemala & 24.10 & Guatemala & 39.50 \\
\hline Haiti & 3.10 & Haiti & 3.00 & Haiti & 5.40 & Haiti & 2.10 \\
\hline Honduras & 0.80 & Honduras & 2.80 & Honduras & 11.20 & Honduras & 127.50 \\
\hline Mexico & 10.10 & Mexico & 70.60 & Mexico & 111.10 & Mexico & 251.60 \\
\hline Nicaragua & 10.40 & Nicaragua & 6.40 & Nicaragua & 9.70 & Nicaragua & 19.60 \\
\hline Peru & 17.30 & Peru & 27.50 & Peru & 91.40 & Peru & 89.60 \\
\hline Uruguay & 278.60 & Uruguay & 360.30 & Uruguay & 449.80 & Uruguay & 287.20 \\
\hline Venezuela & 11.60 & Venezuela & 5.50 & Venezuela & 9.20 & Venezuela & 26.40 \\
\hline \multicolumn{8}{|c|}{ Measures outside the region } \\
\hline United States & $3,571.60$ & United States & $4,913.20$ & United States & $7,869.80$ & United States & $\begin{array}{ll}\mathrm{s} & 8,889.90\end{array}$ \\
\hline Spain & 123.00 & Spain & 194.20 & Spain & 274.30 & Spain & 255.10 \\
\hline
\end{tabular}

Notes: Modern energy includes fossil plus hydroelectric consumption.

*TOE/cap is the tonnes-of-oil equivalent per 1,000 habitants.

**Cuba was a Spanish colony until 1898.

Source: Table 6 in Rubio et al. (2010)

A final note of caution: the per-capita levels mask the actual sizes of some of these countries. For instance, Brazil and Mexico appear to be small players in per-capita terms, when they were actually two 
of the largest overall consumers. In fact, for most of the first half of the $20^{\text {th }}$ century, over $90 \%$ of the total primary consumption of modern energy in Latin America was accomplished by just six countries: Argentina, Brazil, Chile, Cuba, Mexico and Uruguay. This background information should be useful in interpreting the following sections.

\section{THE TRANSITION WITHIN FOSSIL ENERGIES IN LATIN AMERICA}

Possibly, the most commonly used definition of an energy transition is the shift in the predominant fuel. With multiple energy carriers more often than not, no single carrier takes half of the share, just a majority of the energy basket. That shift is recognized as an energy transition. We look at a particular transition (that occurring within fossil fuels) within the larger overall energy transition, with just two energy carriers involved. Therefore, we understand the transition takes place when the carrier taking half of the fossil fuels is replaced for several years in a row by the alternative. A new database on primary energy consumption in Latin America from 1856 to 1960 made it possible to document the transition from coal to oil for 20 countries. Neither the USA nor the European case provides a suitable example for the Latin American experience. The Latin American countries' transitions oscillated to a greater degree, occurred much earlier, and much faster. The Latin American countries offer not one, but at least four types of transition within fossil fuels.

Figure 3: Traditionally shaped transitions from coal to oil but early in time, Argentina (1926) and Brazil (1940)
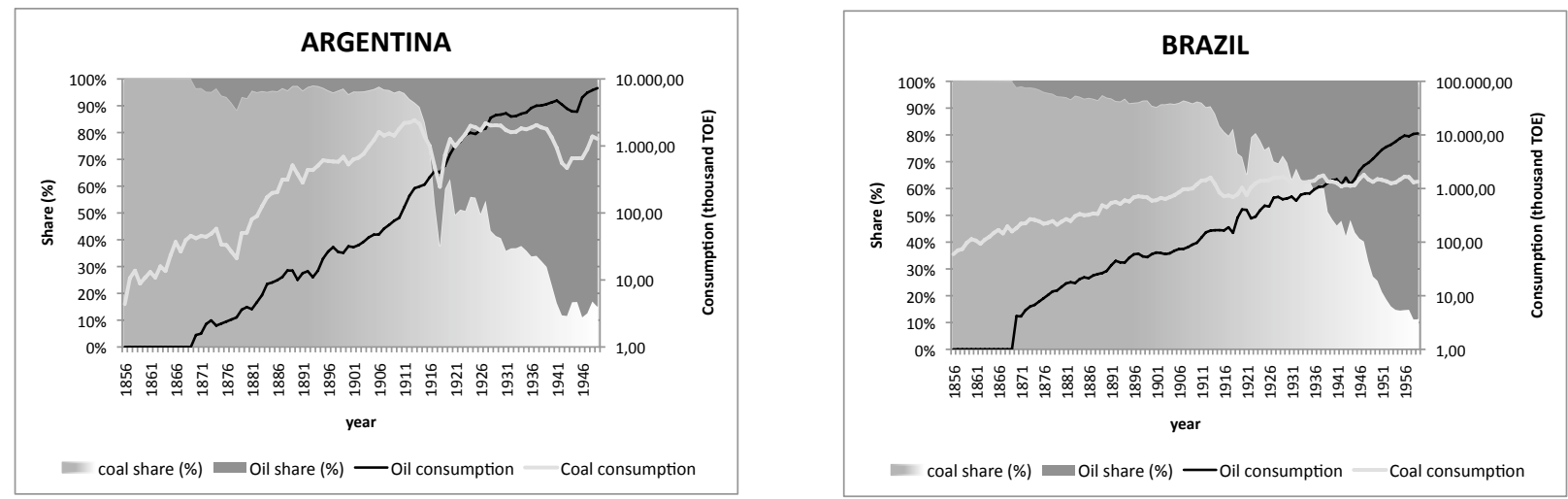

Sources: 1856 to 1870 exports of coal from the United Kingdom to Latin American countries. From 1870 to 1890 the USA exports-as reported by the USA trade statistics - are also included. From 1890 to 1925 the data sources may be found in Rubio et al. (2010). The period after 1925 was completed with ECLAC data and domestic sources for each country. Note the use of a log scale and rescaling for the different countries in the right axis, which refers to primary consumption. 
First, there are the cases of Brazil and Argentina (see figure 3), which most resemble the Western sequence: a relatively long and smooth transition. Nevertheless, both cases are remarkable in terms of one important issue: chronology. In the USA and Europe, petroleum consumption exceeded coal from the year 1950 onwards, whereas in Brazil, one of the last of the Latin American countries to abandon coal, petroleum overtook coal in 1940. In the remainder of the countries in the region, the primacy of petroleum occurs in the 1920 s, that is, 30 or 40 years in advance of the industrialised nations. In the case of Argentina, there is another striking difference, which is shared with most countries in the region. Within 28 years, coal fell from a consumption level of $93.7 \%$ to $10.8 \%$. In the USA, this same transformation took more than 70 years.

There are several exceptions in Latin America, in which coal resisted the competition from oil for many years (see figure 4). In this second type of transition, it is possible to identify a group of countries where coal consumption ebbs and flows in several cycles, and where petroleum only predominates in energy consumption many years into the transition process.

Figure 4: Cases where coal resists and persists: Chile, Colombia and Uruguay
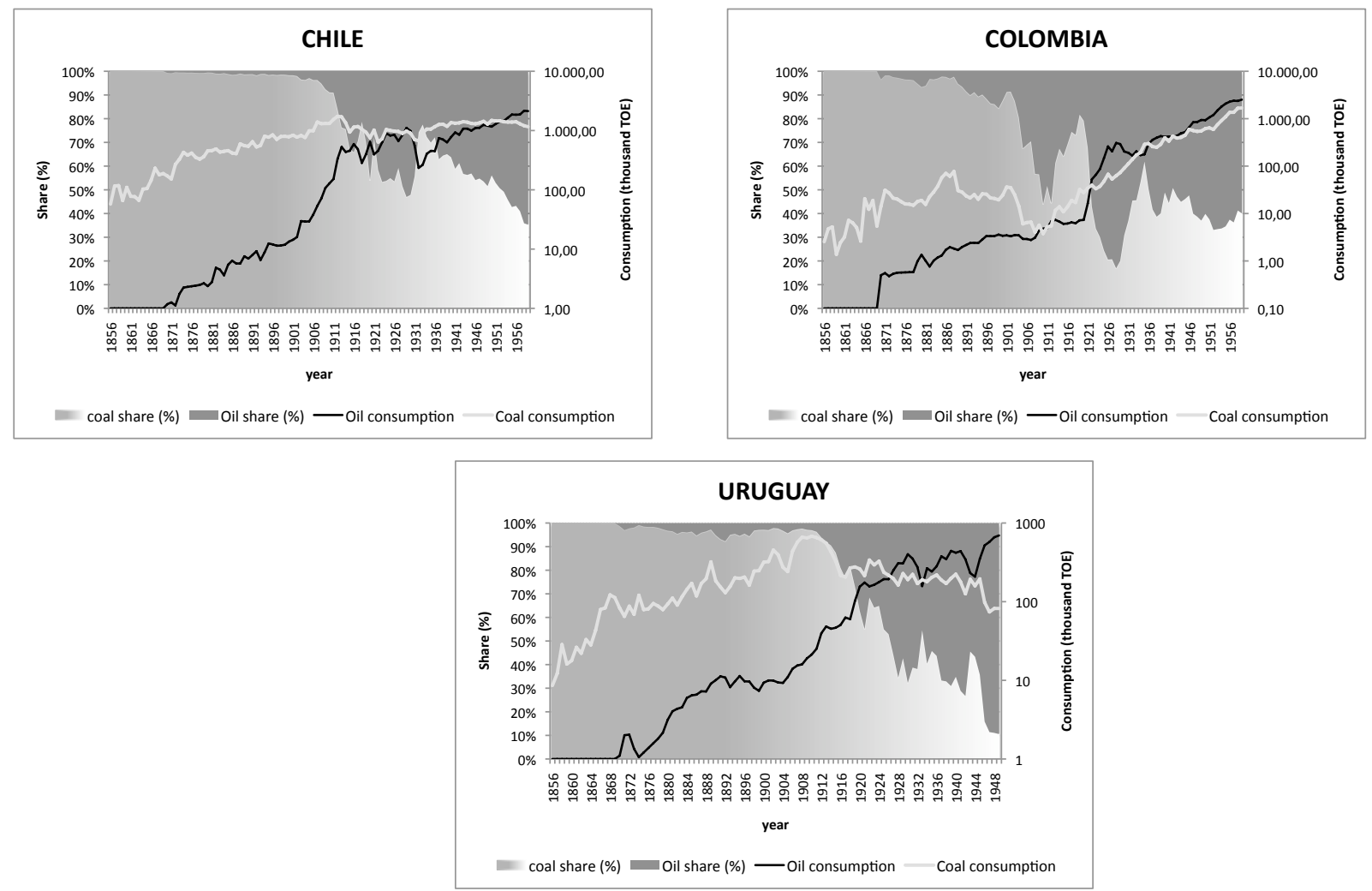
Sources: as in figure 3. Note the use of a log scale and rescaling for the different countries in the right axis, which refers to primary consumption

In the case of Chile, this ambiguity regarding the fossil fuel transition went on for as long as 56 years. It was not until 1961 that coal entered the final phase of descent after three attempts at recovery. In the case of Uruguay, what occurred was similar, although over a shorter time period: 32 years, between 1911 and 1943. Finally, in Colombia (while we acknowledge the poor data on domestic production of coal prior to 1940), coal and oil appear to have been in close competition for over 25 years. Petroleum maintained the higher share of modern primary energy consumption beginning in 1934, but coal retained approximately $40 \%$ of the share until 1960, the largest share of coal in Latin America in the second half of the $20^{\text {th }}$ century.

Sudden transitions, switching from coal to petroleum as the principal fossil fuel within 5 years or less, is the third group observable in Latin America (see figure 5). Costa Rica is possibly the best example of this category. The transition in this country oscillated moderately, as in most cases, but it was surprisingly swift: the transition occurred in barely five years. In 1914, coal accounted for $96 \%$ of the consumption of fossil fuels; by 1919, it had decreased irreversibly to 5.5\%. Additionally, in Cuba, one of the largest consumers both in absolute and per-capita terms, the energy transition took place abruptly: by 1918 , coal had a share of over $70 \%$; and in 1922, coal's share among fossil fuels was only $27 \%$. Mexico and Peru, both large petroleum producers and exporters since the beginning of the $20^{\text {th }}$ century, also experienced sudden transitions in these decades. In both countries, prior to World War I, coal consumption amounted to $70-80 \%$ of fossil-fuel consumption. By the end of the war, coal's share had fallen below $30 \%$. 
Figure 5: Sudden transitions from coal to oil: Costa Rica, Cuba, Mexico and Peru
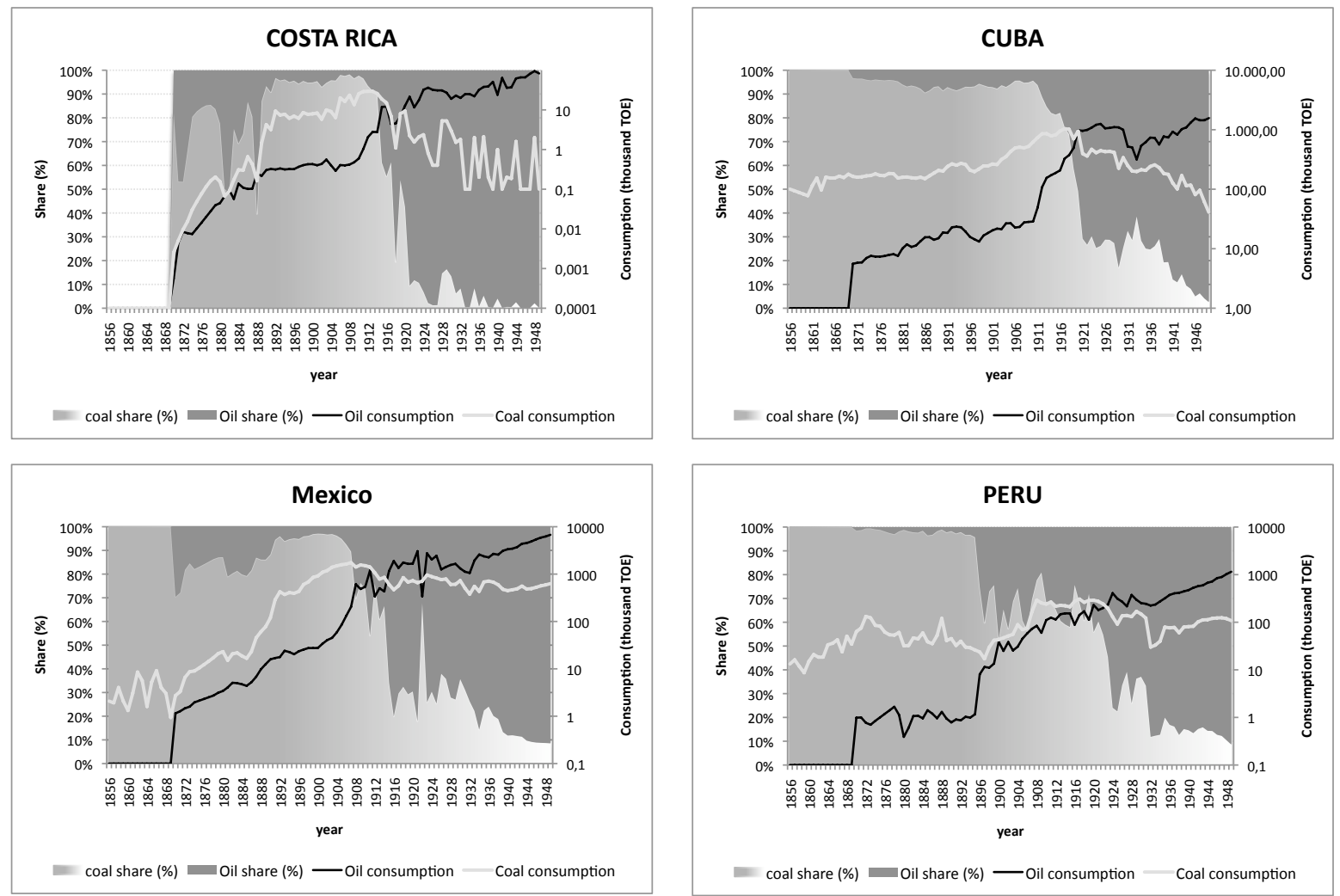

Sources: Same as for figure 3. Note the use of a $\log$ scale and rescaling for the different countries in the right axis, which refers to primary consumption

Most of the remaining Latin American countries also exhibit sudden transitions, but with an additional feature: "inverse transitions" from oil to coal and back to oil (see figure 6). This fourth set of countries entered the fossil-fuel era at the end of the 19th century with petroleum as the main contributor. That is, they enter the fossil fuel era with the unexpected carrier, not following the standard energy ladder of biomass, to coal, and then oil. After some years, coal's position strengthened and experienced a period of primacy for one to two decades. Finally, by the 1920s (or earlier), petroleum displaced coal permanently. This has some resemblance of the rebound of coal in the 1970s after the oil crisis. Yet, in the 1970s despite growing, coal never made a true come back as a predominant fuel, as it did in these cases. 
Figure 6: Inverse transitions from oil to coal and back to abandon coal for good: Ecuador, EI Salvador, Guatemala, Haiti, Honduras, Nicaragua, Dominican Republic, and Venezuela.
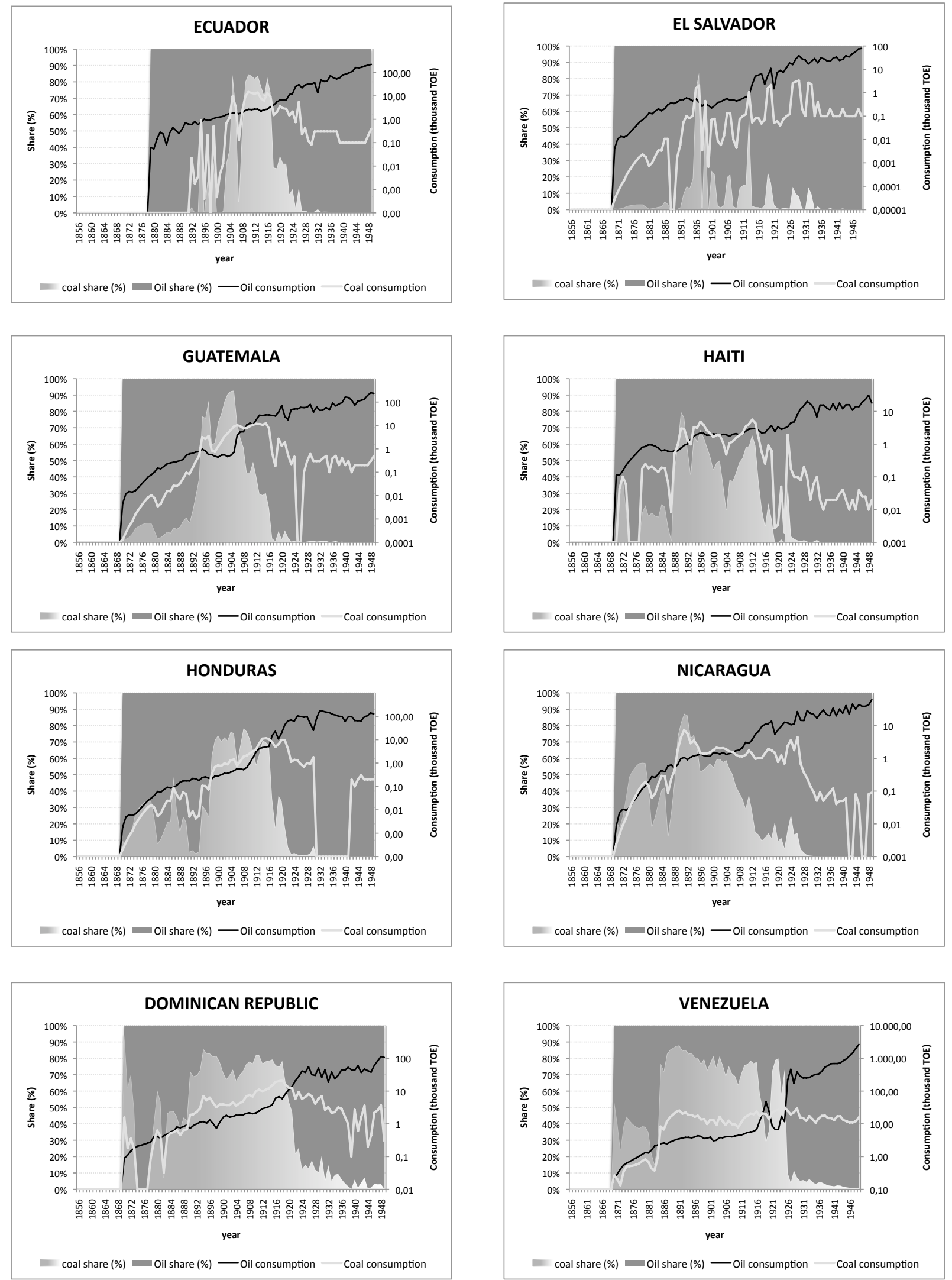

Sources as in figure 3 . Note the use of a log scale and rescaling for the different countries in the right axis, which refers to primary consumption. 
All of the countries in this group of inverse transitions share certain characteristics: 1) all were minor consumers of modern energy, 2) all were underdeveloped economies, and 3) none had a domestic endowment for fossil fuels, except for Venezuela -which became the largest oil producer in Latin America by the end of the 1920s but was fairly underdeveloped before that. In these countries, kerosene lamps arrived before than railways, and when railroads arrived in the late $19^{\text {th }}$ and early $20^{\text {th }}$ centuries, it was already possible to fit locomotives with diesel engines. At the same time, the first automobiles began to arrive. They saw little (if any) of the coal age, leapfrogging the steam engine altogether in some cases.

In summary, despite the wide differences in the transitions within Latin America, there are some common features that contrast with the Western experience. First, Latin America consumed less energy per capita and far less coal than industrialised countries. Second, the substitution of coal with petroleum occurred very early in Latin America (in time and also in relation to GDP levels), compared with the transitions that occurred in industrialised countries. By 1925, only in Brazil was coal still the clearly dominant fossil fuel. Even in countries where coal dominance persisted, such as Chile, coal's share was barely greater than $50 \%$. Third, most Latin American countries made their transitions from coal dominance to oil dominance in a short period of time. Finally, Latin American countries present experiences not found elsewhere: revertible and inverse transitions. Table 3 offers a clear contrast to table 1 in terms of the years in which oil become the predominant fossil fuel in Latin America, compared with the industrialised world. 
Table 3: Fossil fuel transition dates in Latin America

\begin{tabular}{|c|c|}
\hline Country & $\begin{array}{c}\text { Year in } \\
\text { which oil } \\
\text { became } \\
\text { permanently } \\
\text { prevalent } \\
\text { over coal }\end{array}$ \\
\hline Ecuador* & 1896 \\
\hline El Salvador* & 1900 \\
\hline Haiti* & 1903 \\
\hline Nicaragua* & 1906 \\
\hline Guatemala* & 1909 \\
\hline Mexico & 1915 \\
\hline Honduras* & 1917 \\
\hline Venezuela* & 1918 \\
\hline Panama & 1919 \\
\hline Costa Rica & 1920 \\
\hline Cuba & 1920 \\
\hline Dominican Republic* & 1921 \\
\hline Colombia & 1922 \\
\hline Bolivia & 1923 \\
\hline Peru & 1923 \\
\hline Paraguay & 1926 \\
\hline Uruguay & 1927 \\
\hline Argentina & 1928 \\
\hline Brazil & 1940 \\
\hline Chile & 1953 \\
\hline
\end{tabular}

Note: *In these countries, the date marks the year when oil became prevalent over coal for the second time, given that they first made an inverse transition from oil to coal (kerosene to coal) and then back to oil (see figure 6).

Sources: Same as for figure 3

\section{PLAUSIBLE EXPLANATIONS AND LESSONS FOR THE FUTURE}

The Western experience of the energy transition offers a very clear sequence: the power of coal allowed it to advance ahead of traditional energy forms until it dominated all energy systems, including urban, industrial and transport. However, from the beginning of the $20^{\text {th }}$ century, a new energy source, petroleum, began to gain ground steadily. Sixty years later, it had reduced the consumption of coal to $25 \%$ or less. According to Darmstadter et al (1971) by 1925 coal made 37.6 per cent of Latin America primary energy consumption but was only 6.5 per cent by 1968 . Those figures were far below not only of those of the Western world, but also the rest of world regions in both dates: 
for Africa the shares of coal were 91 and 55 per cent respectively; for Asia 92 and 28 per cent; for Oceania 92 and 48 per cent; for Communist Europe and the Soviet Union the percentages were 83 and 53 in those two dates. The question arises as to why Latin America did not follow a similar energytransition path but rather took several different turns.

Before exploring the answer to this question, it is important to note that the energy transitions tend to be expressed in relative terms rather than absolute terms. An energy transition does not necessarily entail the abandonment of coal and of coal technologies. In order for an energy transition to occur, coal and coal technologies, in absolute terms, may remain relatively stable while petroleum and the associated technologies (e.g., the internal combustion engine) grow steadily. In this sense, petroleum does not need to dominate all industrial sectors for an energy transition to occur. Some sectors may continue with coal as the dominant energy source. However, in order for the transition to occur, economic activities that originally include petroleum technologies (e.g., automobiles), or those that could convert to petroleum technologies (e.g., railways, ships, prime movers, thermoelectricity, etc.), expand more than those that continue to use coal.

With respect to the forces driving the advance of petroleum, there is no doubt that the most important is the price per calorie unit. Interestingly, in its early years, petroleum was more expensive to produce than coal. Nevertheless, petroleum was much cheaper to transport by tanker or pipeline than was coal. ${ }^{16}$ The greater the distance that fuel needed to be transported, the greater the price competitiveness of petroleum, an important factor for Latin American ports located long distances from coal mines. In fact, for most of the first half of the $20^{\text {th }}$ century, transporting coal to Latin America was twice as expensive as transporting oil (quality differences acknowledged) (Bertoni et al. 2009).

Along with the relationship with price per calorie unit at the point of consumption, petroleum had other technical attributes, such as versatility, weight and volume, that gave it an absolute advantage

16 Richard Rodhes has argued that "oil might have declined, because it was much more expensive per unit of energy than coal, but because it is a liquid it is also much cheaper to transport. Even as late as 1955, the cost per mile of transporting a ton of liquid fuel energy by tanker or pipeline was less than 15 percent of the cost of transporting an equal amount of coal energy by train". See Rodhes (2002). 
over coal in important sectors such as motorised transport. ${ }^{17}$ We must add to this explanation that the penetration of a product into markets is not simply a consequence of free-market activity, but rather it is also a consequence of policy choices and the effectiveness of the lobbying strategies developed by the companies that trade in these products. In this sense, the petroleum companies - the first large companies and the first trust in history-left an indelible mark. ${ }^{18}$

An explanation of the energy-transition experiences in Latin America requires the establishment of a new research agenda that considers the multiple factors affecting both the relative and absolute advance of petroleum along with the relative retreat and stagnation or the absolute decline of coal in each country. Such an analysis is beyond the scope of this article. Nevertheless, we are able to advance general hypotheses based on the examination of the data.

The first line of interpretation is that the countries that began the process of industrialisation early (Argentina, Chile, Uruguay and Brazil), and therefore had a relatively high level of energy consumption (coal was the only option in the early years), tended to maintain the classic pattern of energy consumption based on coal. This may be a manifestation of path dependence, wherein switching to petroleum may be impeded by the existence of previously installed coal-burning machinery that is still in good condition. On the contrary, for countries that industrialised later, where coal technologies were absent or scarce, it was natural to adopt the new technologies using liquid fuels. In the lessindustrialised countries, fossil fuel consumption was reduced, was present in fewer productive sectors and was likely the result of decisions by a smaller number of companies. This type was predominant in Central America and the Caribbean at the beginning of the century. Furthermore, as is shown in figure no. 7 , the smaller the level of consumption, the faster and the earlier the transition was, possibly

17 Grübler introduces an interesting nuance to this argument. He claims that "it is important to recognise that these two major historical shifts were not driven by resource scarcity or by direct economic signals such as prices, even if these exert an influence at various times. Put simply, it was not the scarcity of coal that led to the introduction of more expensive oil. Instead, these major historical shifts were, first of all, technology shifts, particularly at the level of energy end use". (Grübler, (2004) "Transitions in Energy Use”, op cit, p.: 170).

18 For further discussion of this topic, see Pratt (1983). 
because the replacement costs were minor when few machines/factories/sectors were involved. In other words, the greatest consumers of coal took the longest to leave it behind.

Figure 7: The greater the coal consumption, the slower the transition from coal

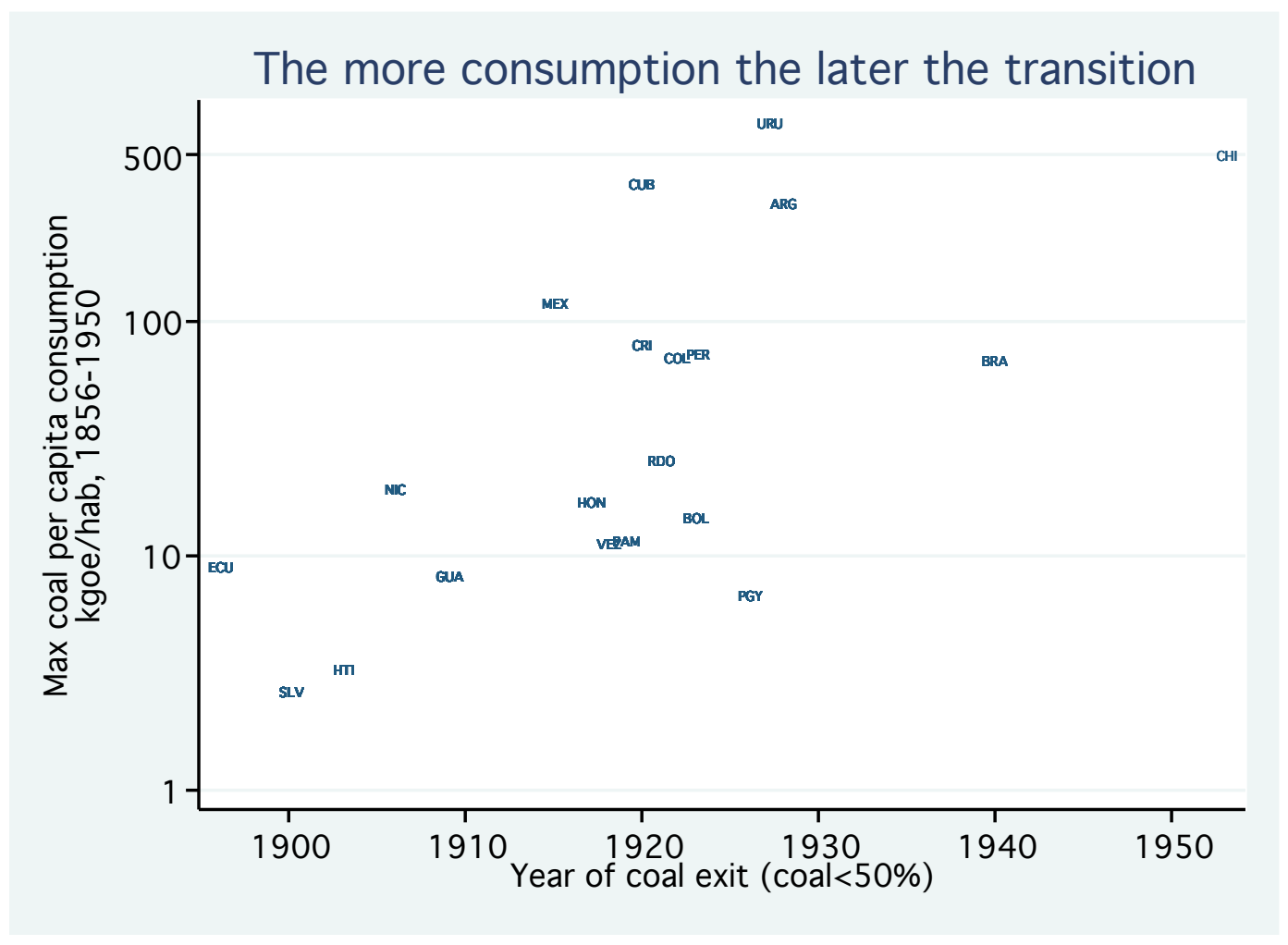

Sources: Same as for figure 3

The second line of interpretation relates to trade networks. In the case of Argentina, its historical trade ties with Great Britain turned it into a great consumer of British fuel (coal) and associated technologies for many years. In the case of other Latin American and Caribbean countries, there is no doubt that the geographical proximity, trade ties and the presence of significant fuelconsuming North American companies (e.g., United Fruit Co.) favoured the rapid adoption of petroleum. Along these lines, Carreras-Marin and Badía (2008) demonstrate that countries with the USA as a coal supplier displayed a positive bias towards an early transition to oil. Countries buying coal from the United Kingdom tended toward coal-consumption persistence. 
A third explanatory variable is factor endowments. Taken as a unit, Latin America has historically produced oil in excess of its consumption but lacked needed coal. The commercial inertia that tied Argentina to Great Britain was broken when Argentina began to exploit its own oilfields. From that time forward, coal imports dropped irreversibly. In the case of Chile, the initial situation was similar to that of Argentina in terms of commercial partners, but the transition path was different because of Chile's own resource endowment (coal). Chilean industrialisation began relatively early, fed first by imported coal and later by domestic coal. The probable reason for the delayed abandonment of coal in Chile, as well as the unusual cycles of recovery of coal throughout the industrialisation process, can be found in successive policies of promotion of national development, which obliged a large proportion of consumers to favour domestic coal over imported petroleum. National policies should thus also be part of the research agenda, and not only as they relate to the use of domestic-versusimported energy sources. In the case of Uruguay, Bertoni et al. (2009) report that during the first third of the $20^{\text {th }}$ century, the government pursued a strategy to favour American capital investors to "shake off the British yoke". Such promotion included the construction of infrastructure, such as paved roads, to facilitate the adoption of cars and trucks. As a result, Uruguay registered double the number of vehicles per capita than did Spain in the first third of the $20^{\text {th }}$ century. Thus, policy matters in more than one way when it comes to technological adoption.

Income distribution may also have a roll to play in the early adoption of modern technologies in less advanced countries. Higher income groups have consumption patterns that echo these of more advance countries. This is relevant for Latin America, because it has never been among the poorest regions of the world, but it is historically the region with the largest income inequality of the world (Deininger and Squire, 1996; Prados, 2007; Williamson, 2010). That might help to understand why oil was no swiftly adopted in Africa - poorer both in economic and energetic terms than Latin America; Africa might had been too poor for a meaningful advance of the combustion engine during most of the $20^{\text {th }}$ century, as some of the poorest countries of our sample were too poor to adopt the steam engine back in the $19^{\text {th }}$ century. 
Last but not least, it is not coincidental that a considerable number of countries shifted from coal to petroleum consumption between 1914 and 1919, in the middle of the Great War. The First World War was responsible for the rapid maturity of the petroleum industry. Just prior to the war, both the U.S. and Great Britain began the conversion of their naval fleets from coal to oil burners. Not only did petroleum propel the newest and fastest war vessels but it also provided fuel for such military innovations as the submarine, the tank and the airplane. Evidently, petroleum companies in the USA, the largest oil producer at the time, took advantage of the export restrictions on European coal-supplier countries during the First World War and themselves supplied fuel-hungry countries. And yet the Latin American transition from coal to oil took place within a scenario of oil shortage. The distortions introduced by the War, the Soviet Revolution, the cold winters of the end of the 1910s, plus the final War effort produced the first petroleum shortage of the 20th century between the years 1918 and 1921 (Rubio, 2006). To our purposes, the impact of external shocks on markets and technology should not be underestimated in the analysis of energy transitions.

The historical cases presented, although limited to the shift from coal to oil, demonstrates that the Western experience of energy transition does not apply universally. Looking ahead, this finding has policy implications for both advanced and less-advanced countries.

In light of this evidence, the expectations for the examples of energy transition known to date should be re-examined. If this past experiences projected that the leading economies would set the pace and be the first to reach the next stage, the new evidence seems to imply that leading economies may not be the first to complete the transition leaving fossil fuels behind. History shows that early coal adopters were not particularly quick to abandon it; in fact, the United Kingdom had a slow and belated transition from coal. By the same token, the USA may be the last country to abandon oil dominance. Similarly, the first countries to transition from fossil fuels will likely be those that currently make little (if any) use of them. While the typical expectation for less-developed countries is that they will consume greater quantities of fossil fuels as they develop, the lesson from Latin America's transition is 
that they may 'leapfrog' the combustion engine at once. They may go from low oil consumption today to lower oil consumption in the future.

Nevertheless, the transition is likely to be slow for developed economies, not because they were early adopters, but because they became significant adopters. These two traits go hand in hand. Time allows for a deeper penetration of a technology, a larger market share and larger sunk costs. It is a self-reinforcing mechanism, making the prevalent technology more and more dominant over time. Consequently, time also makes it more difficult to leave that technology behind even if a more efficient alternative emerges. In the case of energy technologies, where the associated infrastructure for production, distribution and usage tend to involve large capital investments in infrastructures and durable goods, the role of accumulated sunk costs seems to be crucial in the pace of the transition. The switching gains may be high, but transition would be impractical, at least while the existing stock of associated capital is in good condition. Thus, path dependence will also play a role in the rate of transition.

That is not to say that the leading world economies will not be involved in the development of the technologies needed for the next energy transition. On the contrary, their research facilities and the innovation of their companies are important in the development of viable alternatives. However, the dissemination and dominance of those technologies will likely take place earlier elsewhere. Most of the combustion engine technological advances took place in the United States and Europe, but they were more quickly adopted and dominated the market earlier in Latin America than in any of the countries that developed the technology, as seen in the example of Uruguay above.

The historical examples described above offer several important lessons for the producers of low-carbon technologies. They will stand a better chance of obtaining a meaningful market share, even becoming the dominant technology, in markets where fossil fuels, and combustion engines in particular, have little penetration today. In such markets, they do not have to overcome the costs of replacement and the sunk costs already committed to fossil fuels. Market share may prove to be a crucial factor where network effects are at play. In such cases, a small number of users are required to make a 
technology viable. It may be helpful to consider the example of creating infrastructure for charging electric cars versus creating an alternative network of gas stations. The number of cars produced of each type and the creation of the relevant infrastructure are dependent on one another. Although the gas stations are already in place in advanced economies, a developing country must decide which infrastructure is a better value. Low-carbon technologies can provide a new option as long as their value for energy service is perceived as equivalent to that of the proven technology. In this case, the difference between developed and developing countries is striking. In advanced economies, the objective of, for example, electric-car producers is to replace existing combustion engine cars that are part of a large stock of cars. In developing economies, the objective is to make sure that any new car added to the small stock of cars in the country is electric.

The role of policy and the choice of trade partners today seem to be significant factors for the speed of less-developed countries' energy transition in the future, considering the level of consumption and acknowledging the domestic endowment of energy resources. Leaders of these countries should also beware of a possibility not present in the advanced economies energy transition experiences: reverse transitions, in which the old technology resists, persists and occasionally returns to rein. Today, a return to coal dominance is not out of the scope of possibility for some countries if they do not react promptly.

\section{CONCLUSIONS}

Nowadays, there are about 2.5 billion people relying on biomass for cooking and heating in economies that are barely modern at all. The cases we present are closer to this reality than the historical energy evidence of the Western world. While it is true that the precise nature of the future transition is uncertain, and no standardized transition is expected as such, it is also true that the energy transition phenomenon can only be described as an historical phenomenon. Our paper describes alternative historical types of energy transitions for rather small energy consumers, which do not fit the 
standards of the historical experience of the developed nations. We need to understand this new variation, and the implications it may have for future transitions.

The remarkable form that the shift from coal to oil took in Latin America is worth exploring on its own. Our findings unveil the data and evolution of fossil fuels transition for countries were no previous information was available. Overall, however, this paper questions the universality of the energy transition of advanced economies and its associated features regarding pace, irreversibility and the sequence within the energy transition. According to the evidence presented, large sets of following economies can have earlier and quicker energy transitions than leading nations. The evidence also suggests the existence of alternative sequences (inverse, revertible) in the transition from coal to oil. Furthermore, it demonstrates that 'leapfrogging' may allow following economies to reach the next step of the energy ladder well in advance of the leading economies. The fact that transition is not lineal and the adoption of technology can be faster and not in harmony with a certain level of development does not imply economic and technological convergence. Neither economic nor technological convergence is taking place, for the most part, in the cases presented here.

We find that being a small energy consumer nation makes a difference for the way the energy transition takes place. But is not only the level of consumption what matters. Also path dependence (including trade and technological partnerships), domestic endowment (which dictates relative prices), the extreme income concentration (which facilitated the adoption of modern technology for the top income part of the population) and policy decisions seem to be the variables that shaped the peculiar swift transition from coal to oil in Latin America. We must prepare for different types of energy transitions (including reverse transitions) and must look outside the Western world to understand the array of feasible pathways for future energy transitions. 


\section{REFERENCES}

Baer, Werner (1969). The development of the Brazilian steel industry. Vanderbilt University Press, Nashville, Tenn.

Bashmakov, I. (2007)‘Three laws of energy transitions’, Energy Policy, Volume 35, Issue 7,: 35833594, doi:10.1016/j.enpol.2006.12.023.

Bartoletto, S. and M.d.M.Rubio (2008). "Energy Transition and $\mathrm{CO}_{2}$ Emissions in Southern Europe: Italy and Spain (1861-2000)". Global Environment, 2. pp. 46-81

Bertoni, Reto (2002). Economía y Cambio Técnico. Adopción y Difusión de la Energía Eléctrica en Uruguay (1880-1980), Master's Thesis, Universidad de la República, Social Sciences Faculty, Montevideo.

Bertoni, R., C. Román y M.d.M Rubio, (2009) "El desarrollo energético de España y Uruguay en perspectiva comparada: 1860-2000”, Revista de Historia Industrial, No41 (3) pp. 161-194

Brannstrom, C. (2005). "Was Brazilian industrialisation fuelled by wood? Evaluating São Paulo's energy hinterlands, 1900-1960", Environment \& History, 11(4): 395-430.

Burke, Paul J.,(2011) 'The National-Level Energy Ladder and its Carbon Implications' (November 1, 2011). Available at SSRN: http://dx.doi.org/10.2139/ssrn.1952909

Caetano Bacha, Carlos Jos (2003). "The Evolution of Wood-based Industries in Brazil and their Means of Securing Word”. Oxford Development Studies, 31(2): 197-217.

Carreras, Albert, Mauricio Folchi, Andre Hofman, Mar Rubio, Xavier Tafunell y César Yáñez,(2006) "Importaciones y modernización económica en América Latina durante la primera mitad del siglo XX. Las claves de un programa de investigación”, Serie Estudios Estadísticos y Prospectivos de la CEPAL, $\mathrm{N}^{\mathrm{0}} 44$,

Carreras-Marín, Anna and Marc Badía,"The First World War and coal trade geography in Latin America and the Caribbean (1890-1930)", Jahrbuch für Geschichte Lateinamerikas, (2008)

Cleveland, Cutler (Lead Author); Dagmar Budikova (Topic Editor). 2008. "Energy quality." In: Encyclopedia of Earth. Eds. Cutler J. Cleveland (Washington, D.C.: Environmental Information Coalition, National Council for Science and the Environment). [First published in the Encyclopedia of Earth February 22, 2007; Last revised November 18, 2008; Retrieved September 18, 2009]. <http://www.eoearth.org/article/Energy_quality>

Darmstadter, Joel and Perry D. Teitelbaum and Jaroslav G. Polach,(1971). Energy in the world economy; a statistical review of trends in output, trade, and consumption since 1925. Baltimore, Resources for the Future, the Johns Hopkins Press.

Dean, Warren (1995). With Broadax and Firebrand: The Destruction of the Brazilian Atlantic Forest, University of California Press, Berkeley.

Deininger, K. and Squire, L, (1996) 'A New Data Set Measuring Income Inequality', World Bank Economic Review 10(3): 565-591 doi:10.1093/wber/10.3.565

Diamond, J. M. (1999). Guns, germs, and steel: The fates of human societies. New York: Norton.

Dunkerley, J. (1980). "Energy Use Trends in Industrial Countries: Implications for Conservation", The Energy Journal, 8(2): 105-115. 
ECLAC (1951). Estudio Económico de América Latina 1949, New York.

ECLAC (1956). La energía en América Latina. Instituto de Desarrollo Económico, Internal Bank for Reconstruction and Development, Washington, D.C.

Folchi, Mauricio (2001). "La insustentabilidad de la industria del cobre en Chile: los hornos y los bosques durante el siglo XIX", Mapocho, Santiago de Chile, 49: 149-175.

Folchi, Mauricio y Mar Rubio(2007). "El consumo aparente de Energía fósil en los países latinoamericanos hacia 1925: una propuesta metodológica a partir de las estadísticas de comercio exterior", Estudios estadísticos y prospectivos de la CEPAL, ECLAC, Santiago de Chile, 47: 172.

Folchi, Mauricio y Mar Rubio, (2008). "El consumo aparente de energía fósil en los países latinoamericanos en 1925: una propuesta metodológica a partir de las estadísticas de comercio exterior", in Rubio y Bertoni (eds.), Energía y Desarrollo en el largo siglo XX: Uruguay en el marco Latinoamericano, Montevideo: 19-72.

Fouquet, Roger, (2010). The slow search for solutions: Lessons from historical energy transitions by sector and service, Energy Policy, Elsevier, vol. 38(11), pages 6586-6596, November.Fouquet, R. and Pearson, P. J. G. (1998). "A Thousand Years of Energy Use in the United Kingdom". The Energy Journal, 19(4): 1-41.

Fouquet R. and Pearson, P. "A thousand years of energy use in the United Kingdom," The Energy Journal, vol. 14, 1998, pp. 1-41.

Funes, Reinaldo (2004). De bosque a sabana. Azúcar, deforestación y medio ambiente en Cuba: 1492 1926, Siglo XXI, México D.F.

Gales, Ben; Astrid Kander; Paolo Malanima and Mar Rubio (2007). "North versus South: Energy transition and energy intensity in Europe over 200 years". European Review of Economic History, 11(2): 219-253.

Gibbons, John H. and Peter D. Blair, (1991), 'US energy transition: on getting from here to there',-

Physics Today, pp.22-30

Grübler, A. (2004). “Transitions in Energy Use”, Encyclopedia of Energy, Elsevier, 6: 163-177.

Grübler, A. (2008) (Lead Author); Cutler Cleveland (Topic Editor) "Energy transitions". In: Encyclopedia of Earth. Eds. Cutler J. Cleveland (Washington, D.C.: Environmental Information Coalition, National Council for Science and the Environment). $<\mathrm{http}$ ://www.eoearth.org/article/Energy_transitions $>$

Hobson, J. A. (1914). Work and wealth: A human valuation, New York.

Hunt, L, And Y Ninomiya. 2005. Primary Energy Demand In Japan: An Empirical Analysis Of LongTerm Trends And Future Co Emissions. Energy Policy 33, No. 11 (7): 1409-1424.

Japan, The Energy Data and Modelling Center (1996), Institute of Energy Economics, Tokyo

Kander, A. (2002). Economic Growth, Energy Consumption and CO2 Emissions in Sweden 1800-2000. Lund Studies in Economic History no. 19.

Krausman, Fridolin and Helmut Haberl (2002), "The process of industrialization from the perspective of energetic metabolism. Socioeconomic energy flows in Austria 1830-1995", Ecological Economics, 41(2): 177-201.

Leach, Gerald (1992). “The Energy Transition”, Energy Policy, 20(2): 116-123.

Maddison, Angus (2003). The World Economy: Historical Statistics. OECD Development Centre, Paris. 
Malanima, Paolo. (2006). Energy consumption in Italy in the 19th and 20th centuries: a statistical outline. [Naples]: Consiglio nazionale Delle Ricerche Istituto Di Studi Sulle Società Del Mediterraneo.

Marcotullio, Peter J. and Niels B. Schulz (2007), "Comparison of Energy Transitions in the United States and Developing and Industrializing Economies". World Development, 35(10): 1650-1683.

McNeill, John R. (2002), "El sistema internacional y el cambio ambiental en el siglo XX", Ayer, Revista de historia contemporánea, 46: 19-42.

Melosi, Martin V. (1982). "Energy Transitions in the Nineteenth-Century Economy", in George H. Daniels and Mark H. Rose, eds., Energy and Transport: Historical Perspectives on Policy Issues, Beverly Hills, CA., Sage Publications, pp. 55-69.

Mumford, L., Technics and civilisation (NewYork, 1934).

Murphy, James T. (2001), Making the energy transition in rural east Africa: Is leapfrogging an alternative?, Technological Forecasting and Social Change, Volume 68, Issue 2, October

Nye, David E. (1998). Consuming power: a social history of American energies, MIT Press, Cambridge, Mass.

Peake, Stephen (1994). Transport in Transition: Lessons from the History of Energy, Earthscan, London.

Prados de la Escosura, L. (2007), "Inequality and Poverty in Latin America: A Long-Run Exploration", in T.J. Hatton, K.H. O’Rourke, and A.M. Taylor (eds.), The New Comparative Economic History, Cambridge, Ma: M.I.T. Press, pp. 291-315.

Pratt, J. (1983). "El ascenso del petróleo: la transición de carbón al petróleo en los Estados Unidos a comienzos del siglo XX', en Pelerman, L, Giebelhaus, A., Yokell, M. Transiciones de las Fuentes Energía: perspectivas largo plazo, Buenos Aires: 17-39. [original edition in English by the American Association for the Advancement of Science, 1981]

Read, T. T. (1933). "The World's Output of Work", American Economic Review, 23(1): 55-60.

Restrepo, M.A. (1953), El Rey de la Leña, re-edited by Eskeletra Editorial, (2010).

Rodhes, Richard (2002). "Energy Transitions: a history lesson", 6th International Symposium on Fusion Nuclear Technology, San Diego, USA.

Rosenberg, Nathan (1982). "The effects of energy supply characteristics on technology and economic growth", in Nathan Rosenberg, Inside the Black Box: Technology and Economics. Cambridge University Press, New York: 81-103.

Rubio, M. d. Mar, (2005). "Energía, economía y CO2: España 1850-2000”, Cuadernos Económicos de ICE, 2(70): 51-71.

Rubio, M.d. Mar (2006), "The Role of Mexico in the First World Oil Shortage: 1918-1922 an International Perspective", Revista de Historia Económica-A Journal of Iberian and Latin American Economic History, Nº1, Año XXIV, pp.69-96

Rubio, M. d. Mar. y Mauricio Folchi (2005). "Energy as an Indicator of Modernisation in Latin America by 1925”, Universidad Pompeu Fabra, Economics \& Business Papers, 868.

Rubio, M. d. Mar, César Yañez, Mauricio Folchi, and Albert Carreras.(2010) "Energy as an indicator of modernization in Latin America, 1890-1925", Economic History Review, vol. 63(3), pages 769-804.

Steward, F.R., Energy consumption in Canada since confederation, Energy Policy, Volume 6, Issue 3, September 1978, Pages 239-245 
Schurr, Sam. H. (1984). "Energy use, Technological Change, and Productive Efficiency: An EconomicHistorical Interpretation". Annual Review of Energy, 9: 409-425.

Schurr, Sam H. and Vera F. Eliasberg (1960). "The changing level and pattern of energy use", in Schurr and Netschert, Energy in the American economy, 1850-1975: An economic study of its history and prospects, The Johns Hopkins Press, Baltimore: pp. 31-44.

Schurr, Sam H. and Bruce C. Netschert (1960). Energy in the American economy, 1850-1975: an economic study of its history and prospects, The Johns Hopkins Press, Baltimore.

Smil, Vaclav (2000), "Energy in the Twentieth Century: Resources, Conversions, Costs, Uses, and Consequences". Annual Review of Energy and the Environment, 25:21-51.

Smil, Vaclav. (2006). 21st century energy: Some sobering thoughts. OECD Observer 258/59: 22-23.

Teives Henriquez, S., (2011) Enerrgy transitions, economic growth and structural change: Portugal in comparative perspective, Phd dissertation, Lund University, Sweden

U.S. Department of Commerce by Bradley, J.R., (1931). Fuel and Power in Latin America, United States Government Printing Office, Washington.

United Nations (1951). World Energy Supplies in selected years, 1929-1950. Statistical Office of the United Nations, New York.

Warde, P. 2007. Energy Consumption in England and Wales, 1560-2004. Naples: Consiglio Nazionale della Ricerche.

Williams, M. (1982). "Clearing the United States forest: pivotal years", Journal of Historical Geography, 8(1): 12-28.

Williamson, J. (2010), 'Five centuries of Latin American income inequality' Revista de Historia Económica / Journal of Iberian and Latin American Economic History 28 (2): pp 227 - 252, doi:10.1017/S0212610910000078

Wrigley, E. A. (2004), Poverty, progress and population, Cambridge University Press, Cambridge 